\title{
Behave or be banned? Banning orders and selective exclusion from public space
}

\author{
Marc Schuilenburg ${ }^{1}$
}

Published online: 3 November 2015

(C) The Author(s) 2015. This article is published with open access at Springerlink.com

\begin{abstract}
By describing the practice of banning orders in the Netherlands, we investigate how the involved parties are dealing with their new responsibilities. We describe the way the changes in security management exert further influence in the spatial environment of city centers, and we analyze what this means in terms of equality of rights for all citizens. With this analysis, an attempt to explain the exercise of power beyond the State in policing space in Western countries is provided.
\end{abstract}

"To police and to urbanize is the same thing"-Michel Foucault [1]

\section{Introduction}

Improving justice, upholding the law and protecting society are the cornerstones of a democratic society and help people lead a safe and secure life. The last three decades have witnessed radical changes in the way in which this occurs. Traditionally, the government was viewed as the prime actor responsible for our security. But now, an increasing number of other players have assumed tasks and responsibilities relating to our safety and security. In some cases, they have taken over these duties completely. Private guards monitoring shopping malls, university campuses and airports are a wellknown example [2-5]. ${ }^{1}$ But schools, sports clubs and housing organizations are also made responsible for the concern for safety and security in their policy [6, 7]. As a

\footnotetext{
${ }^{1}$ For example, in 1981, the Netherlands had more than 10,000 private security agents, in comparison to almost 27,000 police officers. This number has now tripled in twenty years' time and is approaching the current number of public police functionaries [74].
}

Marc Schuilenburg

m.b.schuilenburg@vu.nl

1 VU School of Criminology, Department of Criminal Law and Criminology, Faculty of Law, VU University Amsterdam, De Boelelaan 1105, 1081 HV Amsterdam, The Netherlands 
consequence, the government is merely 'one of the players', and no longer has a monopoly on resolving challenges to security [8-10]. This does not mean that the influence of the state has diminished, but it does mean that security issues can no longer be approached from the standpoint of the government's exclusive right. To paraphrase Michel Foucault: "The king is dead, long live the extended royal family" [11].

The 'responsibilization' $[12,13]$ of parties other than the police emanates from the insight that the traditional judicial slant is too restricted to allow an effective approach to the current security issue. Tasks in this domain are increasingly being transferred to other parties. An example is the Collective Pub Ban, a measure taken in the Netherlands in an effort to make pubs, bars and nightclubs co-responsible for maintaining safety and security within the city-center nightlife [14]. Depending on the severity of the conduct, an offender can be denied of entry to these venues for a period of 5 years. During this period, the offender is not allowed to enter the particular pub or any of the other pubs, bars and nightclubs that participate in this measure. In addition, similar sanctions are now being introduced in other Dutch cities, through denials of access to public transport and shopping facilities.

Despite the sizeable body of knowledge of explanations for strategies such as responsibilization to explain the exercise of power beyond the State, little research has been performed in studies of governance about (1) how the new parties are actually dealing with their new responsibilities, (2) the way the changes in security management exert further influence in the spatial environment and (3) what this means in terms of equality of rights for all citizens. In the knowledge that great progress can be made in this field, the remainder of this article unfolds in three parts. First, I will describe the new distribution of responsibility with regard to the organization of security management in the Netherlands. ${ }^{2}$ Second, I will make a contribution to ethnographic research into the regulation of public space by examining two public-private security assemblages, the Collective Pub Ban and the Collective Shop Ban. Finally, I will give a response to normative issues concerning the extent to which the changes in security management lead to a specific use of urban space and in which way this is accompanied by the denial of access to large parts of cities to certain groups. In this way, this article contributes to the growing literature on 'policing space' in Western countries (e.g., [7, $15,16])$.

\section{Regulation of public space in the Netherlands}

Where objective security is concerned, a strong increase in registered crime, in both quality and degree of seriousness, has been visible in the Netherlands since the 1960s. In 1980, the police registered 24 violent crimes per 10,000 inhabitants. This had risen to

\footnotetext{
${ }^{2}$ In this matter, it is important to mention that not all Western countries demonstrate the same development with regard to sharing responsibility in the field of safety and security. For instance, there is still a clear distinction between governmental and private parties in various Anglo-Saxon countries such as the USA. In the Netherlands, since the last third of the twentieth century, there has been a visible tendency for the government to collaborate increasingly with private parties in tackling crime and disorder. Recently, similar developments have been present in other European nations but have yet not produced the same scale and impact as in the Netherlands $[33,75]$. Accordingly, it was interesting to take the Dutch situation as a starting point for this research.
} 
87 per 10,000 inhabitants by 2004 . Over the same period, crime against property rose from 459 to 625 incidents per 10,000 inhabitants. And the number of instances of vandalism and destruction registered by the police also rose substantially: from 65 in 1980 to 132 in 2004, per 10,000 inhabitants [17, 18]. As a consequence, the transference of state's power and responsibility for solving social problems to parties other than the police, particularly ones that operate at a neighborhood level, has been on the Dutch policy agenda since the 1980s. Currently, despite an irrefutable decrease in crime, political notions as 'participation society' accompany this shift, containing normative ideals of a small government and a more active role for citizens, social organizations and business companies to combat crime and disorder. Hence, there is a strong focus on 'crafting citizenship' [19] and 'crafting communities' [20] in which parties such as schools, soccer clubs, housing corporations, shopkeepers' associations, and citizens, for whom the tackling of security is often merely a secondary function, are brought together to organize security in different sites.

To create more coherence in local safety politics, an attempt is being made to realize an, what is called, 'integral approach' of community safety in which the concern for security is a responsibility of 'local security networks' [7, 21, 22]. The underlying idea is that an integral approach will lead to the disappearance of the barriers between organizations, and to a better approach to the problem, the so-called ‘decompartmentalization' ([23]: 810). In this integral approach, which refers to completeness, taking into consideration all underlying causes of insecurity and livability, participating parties will be inspired and motivated to collaborate more, which should lead to a more effective approach to security and livability. Sanctions from the Penal Code may be applied but measures based on Administrative Law and Civil Law may also be taken, such as the removal of opportunities and situations that facilitate crime and disorder [24]. ${ }^{3}$ In addition, there are the practical advantages of the cooperation between the government and other parties itself. These mainly involve what are called 'the learning processes of cooperation' $[25,26]$. This involves the transfer of knowledge between the participating parties as a result of which the cooperation can be reinforced and the aims achieved more quickly and effectively. ${ }^{4}$

The integral approach, and more specifically the combination of preventive and repressive measures ('prepression'), is most evident in the strong orientation toward the design of, and access to, public space. Since 9/11, the governance of the Dutch city center "clearly echoes a mere exclusive discourse" ([27]; see also: [28-30]). Much public space is designed in such a way that unexpected occurrences can be largely neutralized. Moreover, a whole body of regulators is often on call to ensure that social friction is precluded. In that respect, public space increasingly resembles a closed space with a strict admission policy. The move towards 'security-obsessed urbanism' [31] is expressed, on the one hand, in making parties other than the government responsible for the security problem in public space. These parties also apply various forms of

\footnotetext{
${ }^{3}$ These advantages are also central in the 'multi-agency approach'. This approach is used to combat degeneration and petty crime in underprivileged districts [76, 77].

${ }^{4}$ There is also a ripple of criticism, such as the vagueness of the concept of 'integral'and of the validity of the argument that a coherent approach is essential in all those areas [78, 79]. For example, the authorities may hold differing opinions about the precise nature of the problem and about the solution-orientations that are applicable there. Moreover, strong horizontalization may bring the risk of too much or too little governance and coercion, both of which lead to a reduction of the content $[80,81]$.
} 
control. On the other hand, a broad package of new measures and instruments, such as CCTV cameras, radars and other control and detection devices, preventive frisking, loitering prohibitions, and the application of stricter rules against dubious entrepreneurs and firms in order to enhance the quality of the urban environment ([32]; see also: [15]).

Among the most taken for granted forms of the integral approach of public space in the Netherlands are banning orders by which offenders are denied access or may only enter public space under supervision. The denial of access to an area is possible on the basis of the covenant that has been locally agreed between the municipality and the participating parties. In addition to the ban, any punishable offense is reported to the police. This occurs with a first infringement and with any subsequent violation of the code of behavior, which is a punishable offense according to Article 138 of the Dutch Penal Code. An important driving force for this development includes ideas that have arrived from the United Kingdom and are known under the name of the 'Anti Social Behavior Order' [33-35]. In this framework, passed as a part of the Crime and Disorder Act 1998, measures are implemented to combat troublesome behavior such as vandalism, rubbish on the streets, public drunkenness, noise disorder, and neighbor abuse. The related measures involve a ban on entering certain areas or associating with certain people. Although a number of critical comments have been made on the effects of AntiSocial Behavior Orders (e.g., [36, 37]), policy makers and politicians still assume that these ideas are effective and could also be applied in the Netherlands.

\section{Methodology}

Over the past 6 years, my colleagues and I have researched and written about the empirical practice of community safety in the Netherlands (e.g., [14, 38-41]). Whereas tackling these forms of insecurity is mainly seen as one of the duties of the Dutch state, the clear demarcation of governmental tasks and tasks of other parties is coming under increasing pressure. The complexity of security is linked to the number of organizations that are attempting to resolve issues of community safety, and to the nature of the measures employed to tackle the problems. This being the case, there is mention of 'a hybrid security model' [7], with a rich and varied picture of responsibility and representation.

The actual situation has consequences not only for more abstract concepts such as citizenship and the spatial infrastructure of the city, but also impinges upon the concrete execution of security tasks. In order to acquire a clear picture of what has changed with respect to such issues, I present the results into the activities of private parties and the effects of these on the collaboration with other organizations in two Dutch local security assemblages involved in combating crime and disorder: the Collective Pub Ban (CPB) and the Collective Shop Ban (CSB) [14, 42]. Both measures, CPB and $\mathrm{CSB}$, arose as a reaction to increasing concern in Dutch business circles about the security of public space and the damage incurred as a result of criminal activity, such as theft, harassment, violence, drunkenness and vandalism. According to the local entrepreneurs, the classical reactions - detection and punishment - of the police and the public prosecutor provided an inadequate response to the problems of crime and disorder. For this reason, entrepreneurs developed their own security measures, such as the imposition of a shop or pub ban on troublemakers, which is enforced throughout 
the entire city center. The new element of the CPB and CSB is the fact that the ban applies not only to the enterprise where it is imposed, but also to all the enterprises that participate in the measure. In this structure, private parties such as shopkeepers, bar staff and commercial security staff (bouncers and door staff) are jointly responsible for tracing and punishing classical offenses, such as theft, abuse, threats and vandalism.

The CPB and the CSB are examples of, what Crawford [43] coined 'contractual governance', whereby local agreements function as instruments of social control of public space. Apparently, this contractual governance accommodates nothing more than a farther-reaching regulation of the social order. In reality, a new set of instruments besides criminal law is being created to keep a grip on the public and moral order of society. The CSB and CPB are civil measures - property and contract form the basis of these measures - and are separate from the criminal law system. This means that the entrepreneurs are primarily responsible for the imposition of a CSB or CPB. A shopkeeper or a hired private security guard decides whether or not someone should be refused entrance. A legislative ground, in the sense of 'a reasonable assumption of guilt', according to Article 127 of the Dutch Penal Code, is not required to enforce the denial. Although criminal law remains present in the background in these banning orders - as a result of the legal authorization of the shopkeeper to arrest someone who is caught red-handed - the established penal process is largely skipped when parties such as bouncers or door staff impose a CSB of CPB (see also: [44, 45]).

For an answer to the question concerning the particular qualities of regulating public space as conceived by the authorities responsible for its regulation, we performed a multiple-case study in four Dutch cities that apply the CPB and CSB: Utrecht (CPB), Amersfoort (CPB), Den Bosch (CPB) and The Hague (CSB). In order to set up a useful research project, we assumed that the local security assemblages to be studied are not passive entities but are "everyday processes of sense-making, symbolic communication, and contested understanding" [46]. Despite formal restrictions such as laws and covenants, there is always scope not to apply the agreed measures (cf. [47]). These issues are relevant because the current study of security is primarily oriented to whether or not a chosen approach actually works, rather than to "why and under which circumstances" ([48]: 70) that may be the case. One is mainly interested in the visible and concrete results of security policy. In that respect, the study of policy outcomes of security measures is well served, particularly with regard to the reduction of crime and the attainment of public trust. However, much investigation into security does a very poor job when describing the thoughts and actions of the authorities that (help) execute security policy, although it is very probable that the interactions and significances that these authorities ascribe to their own and one another's actions can have consequences for the results of a local security assemblage.

The empirical study was carried out by means of interviews, observations at the locations, document research, and study of the literature. Respondents were sampled through a combination of positional analysis (identifying responsible authorities in the city-centers) and snowballing (in which these respondents referred to other key respondents). In total, 171 interviews were held with entrepreneurs, bar staff and commercial security staff (bouncers and door staff), police functionaries and municipal civil servants. The interviews varied in length from half an hour to 2 hours. The number of discussions varied from 84 interviews related to the CPB to 87 interviews with parties that are involved in the CSB. Respondents were asked about their perceptions 
on the official policy of banning orders. Do they nurture opinions other than those agreed upon? Do these opinions have consequences for the execution of their responsibilities? In this way, it was possible to obtain insight into the everyday practice that the parties undertake in the regulation of public space and the approach to security and livability in city-centers in the Netherlands.

\section{Behave or be banned?}

With regard to the practical application and enforcement of the banning orders in the four cities, the research showed important similarities between the four cases that justifies their combined discussion. These similarities concern the willingness of the involved parties to engage actively in the official policy of the banning orders and the way the parties give substance to the agreements made. At least four arguments were put forward, each of which, as I will argue, lead to an uneven treatment of the troublemakers and great uncertainty about the way an offender's case will be treated. The first argument related to the fact that about half of the entrepreneurs are largely unacquainted with the existence of banning orders. Although serious crime problems were the immediate reason for introducing the CPB and CSB, this group claimed that "they never use the measure" or they told us" not knowing exactly why they join". While a great many shops in The Hague have indeed placed a red sticker on their doors, bearing the text: "Admission will be refused to shoplifters and others causing disorder", the salespeople hardly know what the sticker stands for. The interviews also indicate that some shops refused to put the participation sticker on their door or window because "it can detract from the image of a chain of stores", as a police member of staff articulated it.

A second argument is that the various entrepreneurs are largely unacquainted with the way the official forms ought to be used. Although the integral approach in the four cities is replete with administrative forcefulness of expression, such as 'decisiveness', 'persistence' and 'clarity', reality turns out to be somewhat different. The entrepreneurs often do not know where they can request the forms, and consequently do not have them readily available. Those that do have the forms at hand are often unsure about how to fill them out. The police remarked that a great many forms are submitted incorrectly. This means that the bans cannot come into force immediately and they first have to be rectified before they become valid.

The third argument deals with the fact that imposition of the banning orders is faced with all kinds of individual exceptions. According to the respondents interviewed in Utrecht, Amersfoort and Den Bosch, if problems occur with customers, they prefer not to inform or call the police directly. Reasons are fear of a 'whiny image' or, even worse, for an image of a venue where disorderly behavior and violence often take place. Moreover, the respondents in these cities told us that regular customers would have to misbehave more serious than 'passers' [one-time customers, MS] to get an official ban. In the interviews mention was made of 'nepotism', turning a blind eye to the disorder caused by regular customers or by acquaintances. An owner of a pub used the word 'class justice' to emphasize the difference between regular and one-time customers. Much the same happened in the context of the CSB. Shopkeepers mentioned that they would not like to do without their regular customers. Many customers who have 
incurred a CSB in another shop are therefore not denied access to some other shops. "As long as these people behave properly in these shops, they will be allowed entry," as one entrepreneur was keen to stress.

Respondents also prefer informal ways to resolve a conflict with troublemakers. Respondents in both security assemblages claimed that they prefer a verbal denial to the imposition of an official sanction by taking a troublemaker to the back office to fill out the necessary forms. In the case of the CPB, different respondents declared they scarcely need the police in solving incidents: "I'm a talker, that's why I play in on their mind. I'm always willing to put someone out, but that's really the very last means." Furthermore, various respondents mentioned the lack of time to impose a CSB or CPB. No extra time is made available for such activities. Here, too, the entrepreneur's financial considerations form an important motivation for the choices made. For instance, many shops have insufficient staff at their disposal to effectively uphold the CSB. Such cases mostly involve one-man businesses and small shops. The comments made by the manager of a clothing shop in The Hague were illustrative of this: "You do not isolate a thief to ask him politely if he would be good enough to fill out this form." In many cases, small shops simply eject the offenders without reporting any violations.

Finally, a fourth argument is sometimes brought forward stating that various entrepreneurs are reluctant to impose a banning order on the offenders because they are afraid that the police will give their calls over time less attention. Respondents told us that if they call the police too often "their reports at some point will no longer being taken seriously". One respondent we spoke to was clear about the possible consequences of this type of conduct: "It can also work against you if you're going to call the police for every trifle." At the same time, the respondents warned of the effect that "their business can get a bad name to the police and municipality". According to the respondents interviewed, entrepreneurs prefer not to have their place known by the local authority as a place where there is a high chance of violence. This was illustrated by the following quote: "The last thing you want is that the municipality visits you often."

In summary, the emerging mode of regulation associated with banning orders points to intensified social and spatial control of Dutch city centers via formal mechanisms, such as increased surveillance and door security staff. At the same time, the four arguments make clear that one business will be much stricter in the imposition of a CSB or CPB than another. Although both procedures specify a uniform working method to settle cases of disorder and shoplifting, real-life practice indicates that entrepreneurs have difficulty in adhering to this setup. They make all kinds of exceptions to the written agreements and, partly as a consequence of this, the enforcement of order in real-life practice has acquired a more arbitrary character. Although these deviations from the rule frequently have a strongly individual motivation, they are generally based on the same practical considerations, for instance the lack of time to impose a banning order or a double loyalty to certain customers. As a consequence, for an offender, there is great uncertainty about the way his or her case will be treated. This poses questions as to the wisdom of the state in uncritically setting a responsibilization process in motion. It makes relevant the question of whether or not dealing with offenses like theft, fraud, intimidation, and vandalism can be left so easily to private actors such as shopkeepers and bar staff. But it also raises questions about the way the 
banning orders actually lead to a specific use of urban space. It is to this very point that I now return.

\section{Selective exclusion}

It can be stated that one of the consequences of the banning orders is that new spatial orderings are produced in city centers. The CSB and CPB, but also public transport and football banning orders, demand their own place in the city, and have the capacity to draw and control new boundaries in this context. These banning orders mark the transition to rules and prescriptions other than those that prevail in the rest of the city. They manage people in place by enforcing the correct behavior of residents and visitors. People entering these zones are expected to adapt their behavior to the regulations that apply within these areas. As such, the implementation of new sanctions in combination with one's own, formulated rules - regardless of the fact that these are often driven by the best intentions ('doing good') - can give rise to unforeseen social divisions.

A relevant aspect here is that these boundaries present a different reality to different groups in society. In the shadow of the law, these banning orders are devices for, what Hacking [49] called, 'making up' subjects, by which new social categories are constructed out of new forms of security measures. This is shown by the CPB through which offenders can be denied access to large parts of the city center for a period of 5 years. In this way, certain people are excluded from the inner city and the corresponding local facilities. This spatial revolution is perhaps one of the most striking aspects of the responsibilization process. As I mentioned earlier, in that process, an increasing number of areas are being approached with security in mind, and security techniques are being applied on an ever-expanding scale in public space. In conjunction, these changes seem to tell the story of a society gravitating toward the safest point. But they are also accompanied by "an increasing loss of democratic control" [50] and the "restriction of access and free encounters between citizens" (cf. [51, 52]). With this, the question arises as to how security can facilitate inequality and play a role in moral issues concerning who is granted or denied access to certain parts of the city.

The situation that an increasing number of people are being denied access to certain places and the corresponding facilities by banning orders occurs in several countries, such as Germany [53], Australia [54], the United Kingdom [33] and the United States. For instance, Beckett and Herbert $[55,56]$ investigated the way in which undesired people were refused access to various areas in Seattle and the way they reacted to this refusal. The aim of the banishment is to improve the quality of the location in question. Another aim that should justify the ban, it is claimed, is that people who are excluded "are encouraged to desist from any deviant behaviors in which they may engage" ([55]: 105). The authors concluded that it is mainly poor people who are banished, with the black population as the greatest victim of the new security policy. They provide also various arguments why they give preference to the term 'banishment' rather than 'exclusion'. With banishment Beckett and Herbert wish to emphasize the coercive power of the government to refuse people access to certain places by means of an official decree. Moreover, they wish to draw attention to the punitive character of the measure. The problems of the people in question, often beggars, the homeless, drug addicts or immigrants without papers, which Wacquant [57] defined as 'discardable 
categories', are generally seen as criminal issues. In addition, the term closely connects to the experience of the people who are banished. In the Dutch case, Boone and Van Swaaningen [27] have used the same term to point at "the temporary or permanent denial of access to offenders or potential offenders to certain places or functions".

Although no term is perfect, it seems in advance that 'banishment' is too general and has too little relevance to the hybrid security landscape in which this technique is exercised. I have demonstrated that the inclusion and exclusion of people always depends on a specific security assemblage, each of which has its own rules and punishments. Accordingly, I prefer the term 'selective exclusion' due to its more specific meaning. ${ }^{5}$ Selective exclusion reaches further than the term 'banishment', which is associated with a juridical-political form of power-delineated by a "juridical sovereignty and the institution of the state" ([58]: 34; [59]: 102) - and which Foucault called 'classic power' or 'the power of law'. In this latter usage, the emphasis lies on the monopoly of the government to implement rules and sanctions by means of the tools of public legislation, with the state depicted as a 'modern Leviathan' [60] focusing on combating" all imaginable sources of harm" ([61]: 35). In addition, banishment is more related to the removal of people from a community. People are literally 'expelled from the common case' - sent away from a village, city or country - such as in the case of the banished lepers in early modern Europe ([62, 63]: 198; [64]: 145-146; [58]: 43-44). In contrast, 'selective exclusion' is a much more dynamic concept in the study of policing space because it refers to the fact that there are all kinds of social divisions in the city that entail their own public and particular rules of behavior - creating fragmented security at micro-level.

In the case of banning orders, offenders are no longer welcome in distinct parts of cities in which separate social regulations apply and which are under supervision of varying assemblages of police, private security guards and related professionals. From the various examples of the way in which this occurs, it appears that the primary effect of this kind of schism is that certain people are excluded from the facilities in the areas in which they live, and end up in a subordinate and dependent relation to other groups in society. They are temporarily (referring to short periods of time) and, in other cases, permanently excluded from participation in the life that goes on in other parts of the city. In that case, they experience 'civil death', to use an expression of Goffman ([65]: 16), as they lose many of the freedoms that they had taken for granted. These are developments we are seldom aware of, although they exert a determining influence on everyday life.

\section{Concluding thoughts}

In the above discussion I hope to have shown that since the 1980s, the Netherlands has witnessed an ongoing development in which an attempt is being made to find an answer to crime and disorder through cooperation between private and public parties at local level. The new distribution of responsibility in the Netherlands is most lucidly characterized by security assemblages in which local parties, with the aid of the local government, design

\footnotetext{
${ }^{5}$ I have been influenced by the extensive work of Simon on actuarial techniques of insurance, which construct groups along dimensions that erode the basis of collective identity and action. For example, insurers use selection processes to establish "that each person should be assessed precisely in terms of the burden of risk that he creates" ([82]: 784).
} 
their own security program and prescribe certain behavior for people in public space, such as the CSB and the CPB. Regardless of how justified and convincing the banning orders may be in the view of the parties involved, security management does benefit from more clarity about the nature and reach of the measures taken. After all, the instrumental function of security seems to be of greater consequence than the protective function. I have demonstrated that, within certain margins, the official starting points of the covenants are disrupted. In this context I have pointed to the generation of behavioral patterns that seem self-evident to some participants, although they entail the necessary arbitrariness in the implementation and enforcement of the CSB and CPB. For instance, where one shopkeeper may impose the strictest possible version of a banning order, others may be prepared to ignore much of the disorder. These self-organizing processes do not come to expression as a single entity in any of the assemblages studied, but nonetheless they can still cast a shadow on the aim of treating all offenders equally.

Besides being a matter of the protection of citizens against non-legitimate use of coercion and violence, and values like equality of rights and justice, security is also a matter of ordering. Ordering concerns the allocation of places. This spatial process is articulated here and there and is occasionally studied, but it has not yet received the attention it deserves in studies on the governance of security. The literature on security refers to the spatial concentration of crime (in certain neighborhoods for example) and the role of the environment in the genesis of crime, which gave rise to popular criminological theories, such as 'routine activity' theory [66] and 'broken windows' theory $[67,68]$. However, in contrast to many other social sciences, the physical and social setting is not wholly integrated into many studies on security. The spatial context (here regarded as 'the city-center') appears as a 'side-show', stated Hayward ([69]: 87), as something that must be added to the research in retrospect. Besides the physical architecture of locations such as airports and gated communities, I have pointed to a more complex phenomenon. Banning orders, such as the CSB and CPB, demand their own place in the city, and have the capacity to draw and control new boundaries in this context. A relevant aspect here is that these boundaries present a different reality to different groups in society. This is shown by the fact that offenders are excluded from specific areas in the inner city and the corresponding local facilities. I refer to this spatial process as 'selective exclusion'.

The spatial changes in security management have normative consequences that can scarcely be overestimated. They lead to a different view on the theme of the city and the citizen, and also put pressure on classical legal principles and social ideals. In terms of upholding justice, this leads to numerous new questions and problems. For instance, there is the question concerning the classic idea of a city as a unit, as a freely accessible public sphere. Of particular relevance is here how people can assert 'a right to the city', meaning a claim to places rich in qualities and utilitarian value, where there is time for encounter and social intercourse without commercial motives or a profit-and-loss mentality being involved ([70]; see also: [71, 72]). Other questions relate to the problem if we can still think of security as a 'thick public good', understood as an indispensable constituent of any good society [73]. These are questions that generally attract less attention in the literature on security, although they are certainly not less important. I realize that it is easier to pose such questions than to answer them, but answers will have to be found. At this moment, it is striking how little interest Western governments are displaying in the issue of what the new parties are doing with the 
responsibility in security. Not only do the parties scarcely accept public accountability at all, but the governments are also doing nothing to prevent abuse of responsibilities.

Open Access This article is distributed under the terms of the Creative Commons Attribution 4.0 International License (http://creativecommons.org/licenses/by/4.0/), which permits unrestricted use, distribution, and reproduction in any medium, provided you give appropriate credit to the original author(s) and the source, provide a link to the Creative Commons license, and indicate if changes were made.

\section{References}

1. Foucault, M. (2009). Security, territory, population. Lectures at the Collège de France 1977-1978. New York: Picador.

2. Rigakos, G. S., \& Greener, D. R. (2000). Bubbles of governance. private policing and the law in Canada. Canadian Journal of Law and Society, 15(1), 145-185.

3. Shearing, C. D., \& Stenning, P. C. (1983). Private security. implications for social control. Social Problems, 30(5), 493-506.

4. van Steden, R. (2007). Privatizing policing. Describing and explaining the growth of private security. Den Haag: Boom Juridische uitgevers.

5. Wakefield, A. (2003). Selling security. The private policing of public space. Cullompton: Willan.

6. Crawford, A. (1999). The local governance of crime. Appeals to community and partnerships. Oxford: Oxford University Press.

7. Schuilenburg, M. (2015). The securitization of society. Crime, risk, and social order. New York: New York University Press.

8. Johnston, L. (2006). Transnational security governance. In J. Wood \& B. Dupont (Eds.), Democracy, society and the governance of security (pp. 33-51). Cambridge: Cambridge University Press.

9. Johnston, L., \& Shearing, C. (2003). Governing security. Explorations in policing and justice. London: Routledge.

10. Wood, J., \& Kempa, M. (2005). Understanding global trends in policing. Explanatory and normative dimensions. In J. Sheptycki \& A. Wardak (Eds.), Transnational and comparative criminology (pp. 288316). London: Glasshouse Press.

11. Burris, S., Kempa, M., \& Shearing, C. (2008). Changes in governance. a cross-disciplinary review of current scholarship. Akron Law Review, 41(1), 1-66.

12. Garland, D. (1996). The limits of the sovereign state. Strategies of crime control in contemporary society. British Journal of Criminology, 36(4), 445-471.

13. Garland, D. (2001). The culture of control. Crime and social order in contemporary society. Chicago: Chicago University Press.

14. Schuilenburg, M., \& van Steden, R. (2014). De collectieve horeca ontzegging. uitsluiting uit de publieke ruimte? Beleid en Maatschappij, 41(1), 4-18.

15. Lippert, R. K. (2014). Neo-liberalism, police, and the governance of little urban things. Foucault Studies, $18,49-63$.

16. Valverde, M. (2011). Seeing like a city: the dialectic of modern and premodern ways of seeing in urban governance. Law \& Society Review, 45(2), 277-312.

17. Eggen, A. T. J., \& Van der Heide, W. (2005). Criminaliteit en rechtshandhaving 2004. Ontwikkelingen en samenhangen. Den Haag/Voorburg: Ministerie van Justitie/WODC en CBS.

18. Wittebrood, K., \& Nieuwbeerta, P. (2006). Een kwart eeuw stijging in geregistreerde criminaliteit. vooral meer registratie, nauwelijks meer criminaliteit. Tijdschrift voor Criminologie, 48(3), 227-242.

19. Hurenkamp, M., Tonkens, E., \& Duyvendak, J. W. (2012). Crafting citizenship. Negotiating tensions in modern society. London: Palgrave Macmillan.

20. Trommel, W. (2013). The birth of the crafting community. In D. Bannink, H. Bosselaar, \& W. Trommel (Eds.), Crafting local welfare landscapes (pp. 157-171). Den Haag: Eleven International Publishing.

21. Terpstra, J. (2005). Models of local security networks: on the diversity of local security networks in the Netherlands. Crime Prevention \& Community Safety, 7, 37-46.

22. Terpstra, J., \& Kouwenhoven, R. (2004). Samenwerken en netwerken in de lokale veiligheidszorg. Uitgeverij Kerckebosch: Zeist.

23. Niklaus, J. (2012). The influence of the philosophy of police tactics on breaking down social barriers. International Journal of Criminology and Sociological Theory, 5(1), 808-822. 
24. Huisman, W., \& Koemans, M. L. (2008). Administrative measures in crime control. Erasmus Law Review, 1(5), 121-145.

25. Kane, A. A., Argote, L., \& Levine, J. M. (2005). Knowledge transfer between groups via personnel rotation. effects of social identity and knowledge quality. Organizational Behavior and Human Decision Processes, 96, 56-71.

26. Reagans, R., \& McEvily, B. (2003). Network structure and knowledge transfer. the effects of cohesion and range. Administrative Science Quarterly, 48(2), 240-267.

27. Boone, M., \& van Swaaningen, R. (2013). Regression to the mean: Punishment in the Netherlands. In V. Ruggiero \& M. Ryan (Eds.), Punishment in Europe: A critical anatomy of penal systems (pp. 9-32). Basingstoke: Palgrave Macmillan.

28. Downes, D., \& van Swaaningen, R. (2007). The road to dystopia? Changes in the penal climate of the Netherlands. In M. Tonry \& C. Bijleveld (Eds.), Crime and justice in the Netherlands (pp. 31-70). Chicago: University of Chicago Press.

29. van Swaaningen, R. (2005). Public safety and the management of fear. Theoretical Criminology, 9(3), 289-305.

30. van Swaaningen, R. (2008). Sweeping the street. Civil society and community safety in Rotterdam. In J. Shapland (Ed.), Justice, community and civil society. A contested terrain (pp. 87-106). Devon: Willan Publishing.

31. Davis, M. (1992). City of quartz. Excavating the future in Los Angeles. London: Vintage.

32. Vedder, A., van der Wees, L., Koops, B.-J., \& de Hert, P. (2007). Van privacy-paradijs tot controle-staat? Opsporing, terreurbestrijding en privacy aan het begin van de 21ste eeuw. Den Haag: Rathenau Instituut.

33. Crawford, A. (2009). Governing through anti-social behavior. regulatory challenges to criminal justice. British Journal of Criminology, 49(6), 810-831.

34. Field, F. (2003). Neighbours from hell: The politics of behavior. London: Politico's Publishing.

35. Hadfield, P., Lister, S., \& Traynor, P. (2009). 'This town's a different town today': policing and regulating the night-time economy. Criminology and Criminal Justice, 9(4), 465-485.

36. Bullock, K., \& Jones, B. (2004). Acceptable behaviour contracts addressing antisocial behaviour in the London Borough of Islington. London: Home Office.

37. Burney, E. (2002). Talking tough, acting coy: what happened to the anti-social behaviour order? Howard Journal, 41(5), 469-484.

38. Schuilenburg, M., \& van Steden, R. (2014). Praktijken van selectieve uitsluiting. Over de bescherming door en tegen veiligheidsassemblages. In P. Ponsears, L. G. Moor, W. D’haese, \& M. E. Smeets (Eds.), Cahiers politiestudies 30: Politie en haar maatschappelijke partners (pp. 51-62). Maklu: Antwerpen/ Apeldoorn.

39. Schuilenburg, M., \& Van Calster, P. (2009). De collectieve winkelontzegging. Een antwoord van willekeur op overlast'. In H. Boutellier, N. Boonstra, \& M. Ham (Eds.), Omstreden ruimte. Over de organisatie van spontaniteit en veiligheid (pp. 137-155). Amsterdam: Van Gennep.

40. van Steden, R., Schuilenburg, M., Leemeijer, L., \& Loots, L. (2012). Toezichthouders op de tram. een studie naar de handhaving van het ov-verbod in Amsterdam en Rotterdam. Tijdschrift voor Toezicht, 3(4), 9-21.

41. Wesselink, L., Schuilenburg, M., \& Van Calster, P. (2009). De collectieve winkelontzegging. Tijdschrift voor veiligheid, 1(8), 6-19.

42. Van Calster, P., \& Schuilenburg, M. (2012). Beyond criminal law. On the Dutch anti-social behaviour agenda. In G. Vande Walle, E. Van den Herrewegen, \& N. Zurawski (Eds.), Crime, security and surveillance. Effects for the surveillant and the surveilled (pp. 19-33). The Hague: Eleven International Publishing.

43. Crawford, A. (2003). "Contractual governance" of deviant behavior. Journal of Law and Society, 30(4), 479-505.

44. Hobbs, D., Hadfield, P., Lister, S., \& Winlow, S. (2003). Bouncers: Violence and governance in the night time economy. Oxford: Oxford University Press.

45. Hobbs, D., Winlow, S., Hadfield, P., \& Lister, S. (2005). Violent hypocrisy. governance and the night-time economy. European Journal of Criminology, 2(2), 161-183.

46. Ferrell, J. (2013). Cultural criminology and the politics of meaning. Critical Criminology, 21(3), 257-271.

47. Lipsky, M. (1980). Street-level bureaucracy. Dilemma's of the individual in public services. New York: Russell Sage.

48. Nelen, H. (2008). Demystificeren en Verstehen. De toegevoegde waarde van culturele criminologie voor het evaluatieonderzoek. In D. Siegel, F. van Gemert, \& F. Bovenkerk (Eds.), Culturele criminologie (pp. 69-79). Boom Juridische uitgevers: Den Haag. 
49. Hacking, I. (1986). Making up people. In T. Heller, M. Sosna, \& D. Wellbery (Eds.), Reconstructing individualism: Autonomy, individuality and the self in western thought (pp. 222-236). Stanford: Stanford University Press.

50. Schuilenburg, M. (2011). 'The securitization of society. on the rise of quasi-criminal law and selective exclusion, social justice. A Journal of Crime, Conflict, and World Order, 38(1-2), 71-86.

51. Von Hirsch, A., \& Shearing, C. (2001). Exclusion from public space. In A. Von Hirsch, D. Garland, \& A. Wakefield (Eds.), Ethical and social perspectives on situational crime prevention (pp. 77-96). Oxford: Hart Publishing.

52. Young, J. (1999). The exclusive society. Social exclusion, crime and difference in late modernity. London: Sage.

53. Belina, B. (2007). From disciplining to dislocation: area bans in recent urban policing in Germany. European Urban and Regional Studies, 14(4), 321-336.

54. Palmer, D., \& Warren, I. (2014). The pursuit of exclusion through zonal banning'. Australian \& New Zealand Journal of Criminology, $0(0), 1-18$.

55. Beckett, K., \& Herbert, S. (2009). Banished. The new social control in urban America. New York: Oxford University Press.

56. Beckett, K., \& Herbert, S. (2010). Penal boundaries: banishment and the expansion of punishment. Law and Social Inquiry, 35(1), 1-38.

57. Wacquant, L. (2009). Punishing the poor: The neoliberal government of social insecurity. Durham: Duke University Press.

58. Foucault, M. (2003). Abnormal: Lectures at the Collège de France 1974-1975. New York: Picador.

59. Foucault, M. (1980). In C. Gordon (Ed.), Power/Knowledge. Selected interviews \& other writings 1972 1977. New York: Pantheon Books.

60. Hallsworth, S., \& Lea, J. (2011). Reconstructing leviathan: emerging contours of the security state. Theoretical Criminology, 15(2), 141-157.

61. Ericson, R. V. (2007). Crime in an insecure world. Cambridge: Polity Press.

62. Foucault, M. (1975). Surveiller et punir. Naissance de la prison. Paris: Gallimard. English edition.

63. Foucault, M. (1978). Discipline and punish: The birth of the prison. New York: Pantheon.

64. Foucault, M. (2000). In J. D. Faubion (Ed.), Power. New York: The New Press.

65. Goffman, E. (1961). Asylums. Essays on the social situation of mental patients and other inmates. Chicago: Aldine Publishing Company.

66. Cohen, S., \& Felson, M. (1979). Social change and crime rate trends: a routine activity approach. American Sociological Review, 44(4), 588-608.

67. Kelling, G. L., \& Coles, C. (1996). Fixing broken windows. Restoring order and reducing crime in our communities. New York: Random House.

68. Wilson, J. Q., \& Kelling, G. (1982). Broken windows. Atlantic Monthly, 249(3), 29-38.

69. Hayward, K. (2004). City limits. Crime, consumer culture and the urban experience. London: The Glass House.

70. Lefebvre, H. (1996). Writings on cities. Oxford: Blackwell Publishing.

71. Harvey, D. (2008). The right to the city. New Left Review, 53, 23-40.

72. Mitchell, D. (2003). The right to the city. Social justice and the fight for public space. New York: The Guilford Press.

73. Loader, I., \& Walker, N. (2007). Civilizing security. Cambridge: Cambridge University Press.

74. van Steden, R., \& de Waard, J. (2013). 'Acting like chameleons': on the Mcdonaldization of private security. Security Journal, 26(3), 294-309.

75. Edwards, A., \& Hughes, G. (2005). Comparing the governance of safety in Europe. a geo-historical approach. Theoretical Criminology, 9(3), 345-363.

76. Gilling, D. (1994). Multi-agency crime prevention in Britain. the problem of combining situational and social strategies. Crime Prevention Studies, 3, 231-248.

77. Sampson, A., Stubbs, P., Smith, D., Pearson, G., \& Blagg, H. (1988). Crime, localities and the multiagency approach. British Journal of Criminology, 4(28), 478-493.

78. de Haan, W. J. M. (1995). Integrale veiligheid. Beleidsvernieuwing of beleidsvervaging? Justitiële verkenningen, 5, 25-48.

79. Ombudsman Rotterdam. (2007). Baas in eigen huis. 'Tja, wij komen eigenlijk voor alles'. Rotterdam: Rapport van een ambtshalve onderzoek naar de praktijk van huisbezoeken.

80. Prins, R., \& Cachet, L. (2011). Integrale veiligheidszorg en de burgemeester. Tijdschrift voor veiligheid, $1(10), 43-58$.

81. Raad voor Maatschappelijke Ontwikkeling. (2008). De ontkokering voorbij. Slim organiseren voor meer speelruimte. Amsterdam: Uitgeverij SWP.

82. Simon, J. (1988). The ideological effects of actuarial practices. Law \& Society Review, 22(4), 771-800. 